\title{
液体窒素中の熱気泡トリガー絶縁破壊に 与える絶縁フィルムの影響
}

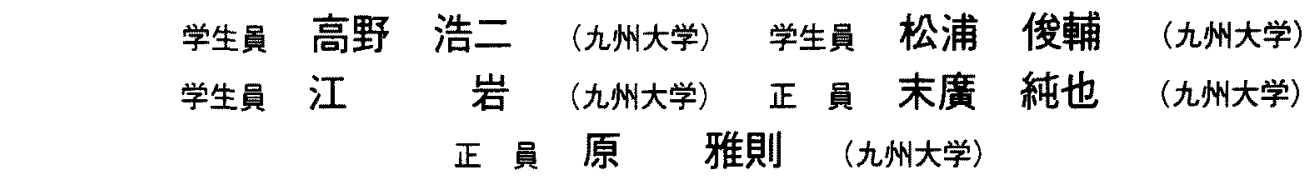

Effect of a Thin Insulation Film on Thermal Bubble-Triggered Breakdown Phenomena in Liquid Nitrogen

Koji Takano, Student Member, Shunsuke Matsuura, Student Member, Jiang Yan, Student Member, Junya Suehiro, Member, and Masanori Hara, Member

(Kyushu University)

\begin{abstract}
Effect of a thin insulation film on breakdown phenomena in liquid nitrogen in the presence of thermally induced bubble is investigated with a cylinder-to-plane electrode. Bubbles were produced by a heater mounted in the cylinder which is partially covered with an insulation film. The results show that the effect of film on the breakdown voltage is little till a pore is formed on the film by a previous breakdown, but it becomes very severe after the pore formation. The reduction rate in breakdown voltage after the pore formation depends on the gap length and heater power. The minimum breakdown voltage reaches down to the gaseous one at normal boiling temperature. Breakdown mechanism is discussed on the basis of bubble observation and numerical calculation of suspended-bubble motion.
\end{abstract}

キーワード：液体窒素、気泡、電気絶縁、絶緑破壊

\section{1. まえがき}

近年、液体㗊素を冷媒として用いる高温超伝導電力機器 の開発が、各地で進められている。特に、電力ケーブル(1) や変圧器(2)等は試作器が製作され、実用化を目指して検討 が進められている。

これらの高温超伝導機器において、高耐電圧化は電流密 度の増大とともに、検討すべき必須の課題である。特に漫 漬冷却超伝導コイルのクエンチ時には、ホットスポットの 付近に高電圧と、絶縁耐力の低い熱気泡とが同時に出現す る状況が考えられる。このような状況は電気絶縁の観点か らは極めて㛜しいものとなる。この事に関して、筆者らは 裸モデル電極を用いて、気泡挙動や絶縁破壊機構について 一連の研究を行ってきた(3)-(9)。また、大久保らは、実際 のコイル環境に近い電極条件でクエンチを起こし、絶縁破 壊の過渡現象の検討を行っている(10)。

ところて、実際の超伝導機器の絶縁構成は、冷媒液体以 外にも広い温度範囲の蒸発ガス、真空、固体、ならびにそ れらの複合系から成る。なかで超伝導線が直接スペーサ や絶縁テープなどの固体に接触する場合には、それらの存 在によって熱気泡の発生状況や電界分布に変化が生じるこ とが考えられる。本研究では、絶縁フィルム被覆が気泡挙 動と秝䋑破壊に与える影響について検討を行い、いくつか の新しい知見を得ることができた。

\section{2. 実験装置と方法}

実験装置の全体図を図1に示す。熱絶縁系は以前から用 いているものと同じで、2層のデュワーを使用しているた め、外部からの熱侵入はほとんどない。使用液体は商用の 液体窒素であり、大気圧下の沸滕温度とした。使用電極は 図2に示すような円筒対平板電極であり、円筒電極内には 超伝導コイルのクエンチ時のジュール発熱を模擬するため に、中央部分にヒー夕を埋め込んである。絶縁フィルムの 影響を調ベるため、厚さ $80 \mu \mathrm{m}$ 、幅 $2.5 \mathrm{~mm}$ のカプトンフィ ルムを、円筒電極の円周に沿って、エポキシ樹脂で接着し た。その際、カプトンフィルムの端からはみ出したエポキ シ樹脂は、研磨剤などにより可能な限り取り除いたが、わ ずかに残り裾野を形成している。実際の超伝導コイルにお

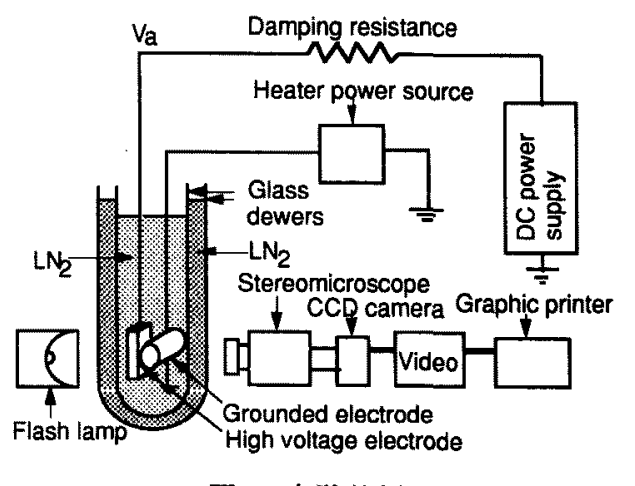

図1 実験装置

Fig.1. Experimental setup. 


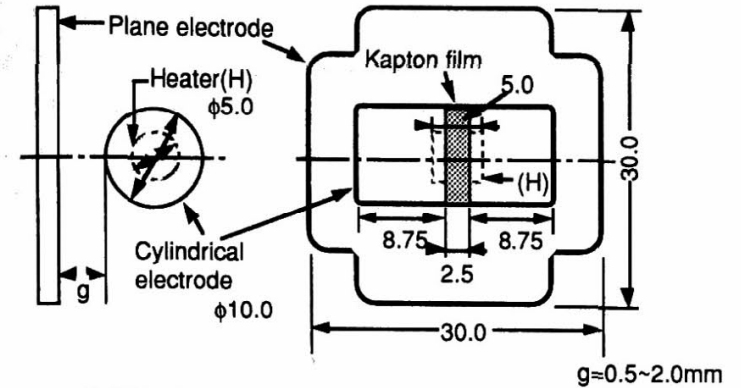

(i) Side view (ii) Front view

図2 電極系

Fig.2. Electrode system.

ける絶縁距離を考慮して、ギャップ長gは0.5〜2.0mmの間 で変化させた。ヒータを持たない平板電極に直流電圧を印 加し、種々の特性を議論する場合の極性は円筒接地電極の それによって表した。破壊電圧は電圧上昇率を約 $1 \mathrm{kV} / \mathrm{s}$ と して測定した。図2に示すように、主として容器壁と超伝 導線を模擬して平板対円筒電極系の軸を横に配置した。以 降の実験および考察は、主に円筒電極を水平にした場合に ついて行ったが、必要に応じて垂直にした場合のデー夕も 示した。以下において特にことわらない限り、円筒電極は 水平に配置したものとする。

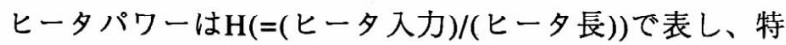
に核沸騰開始の $\mathrm{H} は \mathrm{H}_{0}$ として表した。本実験系の場合、 $\mathrm{H}_{0}$ は電極表面の研磨、絶縁テープの張替、埋込ヒータの交換 の都度多少の変化があった。そこで本研究では、気泡挙動 と破壊特性を論じる場合、沸騰の強さを表すパラメーター はHを $\mathrm{H}_{0}$ で規格化し、Hの小さい領域の特性がより拡大し て示せるように平方根を取って $\sqrt{\mathrm{H} / \mathrm{H}_{0}}$ と表した。

気泡挙動は実体顕微鏡とCCDカメラを通してビデオに 録画し、必要に応じてプリンターで出力した。また、沸騰 開始の時点では、裸電極の場合には設置したヒータの周り に、フィルムを貼った場合にはフィルム端の周りに、気泡 発生の活性核が不均一に分布していた。その分布は電極の 設定毎に多少変化するが、本研究では沸滕開始時点で少な くとも破壊を起こし易い最短ギャップ付近に気泡発生の活 性核のあるものを使用した。

\section{3. 実験結果}

<3.1> 気泡挙動 フィルムなしで $\mathrm{g}=2 \mathrm{~mm}$ および 0.5 $\mathrm{mm}$ の場合の気泡挙動をそれぞれ図3と図4に、またそれ ぞれのギャップ長での破壊電圧付近の最短ギャップの様子 を拡大したスケッチを図5に示す。なお、気泡挙動に対す る極性効果は小さかったので、本研究では後に述べるう に、破壊電圧の低い負極性のデータを図示した。これらの 図から、以前報告したように(6)(8)、次の事が認められた。

(1) $\mathrm{H}_{0}$ 付近のヒータパワーが比較的小さい場合、電圧を 印加することで円筒表面の冷却が促進され、気泡発生が電 圧上曻の途中で観測されなくなる。また、電界による冷却

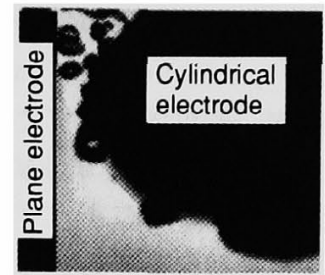

(a) $\mathrm{V}=0 \mathrm{kV}$

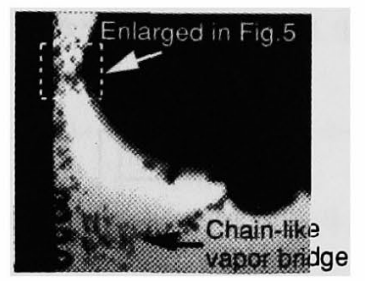

(c) $\mathrm{V}=30 \mathrm{kV}$

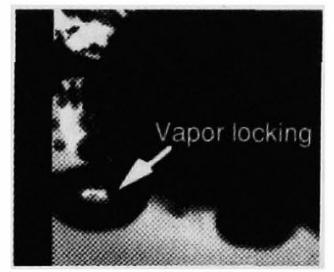

(b) $V=10 \mathrm{kV}$

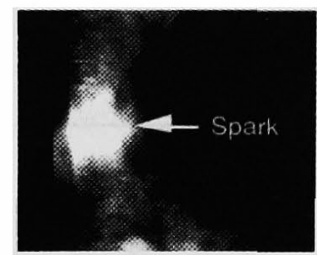

(d) Breakdown
図3 フィルムなしの電極間の気泡挙動 $(\mathrm{g}=2 \mathrm{~mm})$ $\left(\sqrt{\mathrm{H} / \mathrm{H}_{0}}=2.1 、 \mathrm{H}_{0}=0.15 \mathrm{~W} / \mathrm{mm}\right.$ 、負極性)

Fig.3. Bubbles without insulation film at $\mathrm{g}=2 \mathrm{~mm}$.

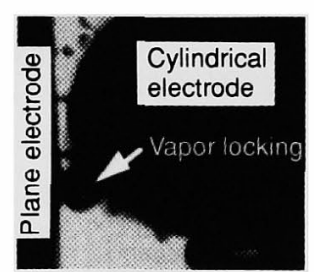

(a) $\mathrm{V}=2 \mathrm{kV}$

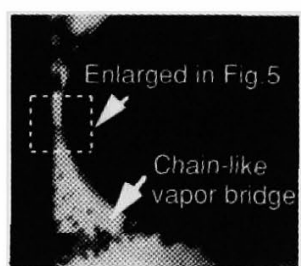

(b) $\mathrm{V}=9 \mathrm{kV}$
図4 フィルムなしの電極間の気泡挙動 $(\mathrm{g}=0.5 \mathrm{~mm})$ ( $\sqrt{\mathrm{H} / \mathrm{H}_{0}}=2.1 、 \mathrm{H}_{0}=0.15 \mathrm{~W} / \mathrm{mm}$ 、負極性)

Fig.4. Bubbles without insulation film at $\mathrm{g}=0.5 \mathrm{~mm}$.

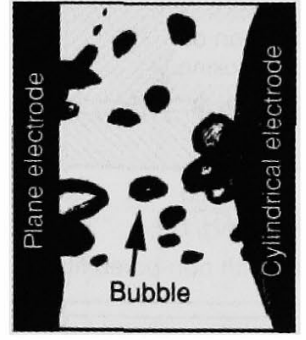

(a) Enlarged in Fig.3(c)

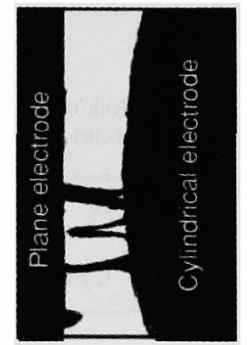

(b) Enlarged in Fig.4(b)
図5 最短ギャップ付近の気泡のスケッチ

Fig.5. Enlarged sketch of shortest gap region.

促進効果と気泡に作用するマクスウェル応力の効果で気泡 が離脱時に長く伸び、気泡半径が電界によって小さくな る。

(2) 図3(b)、図4(a)に示すように、破壊電圧に比べ低い 電圧で、浮力とグレディエント力の釣り合う気泡の滞留位 置(浮力と電界グレディエントカの垂直方向成分が平衡す る位置)において、集塊した気泡による電極間の橋絡が発 生する。

(3) 破壊電圧近くの高い電圧では、滞留位置は最短 ギャップから遠い下方へと移動し、図3(c)、眓4(b)に示す 
ように、集塊していた大きな気泡は細かい気泡の集合へと 変化する。

(4) 高い電圧が印加されている時、最短ギャップでは気 泡表面に作用するマクスウェル応力が大きくなり、図5(a) に示すように、歪んだ気泡が観測される。特にギャップの 短い場合には、図5(b)に示すように、変形して筋状に伸び ギャップ間を橋絡する気泡が観測される。実際に絶縁破壊 が発生するのは、図3(d)に示すように、この部分からとな

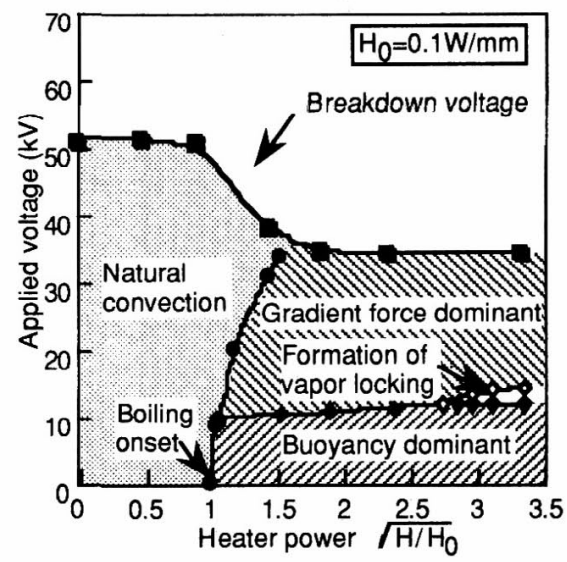

(a) Bared cylinder

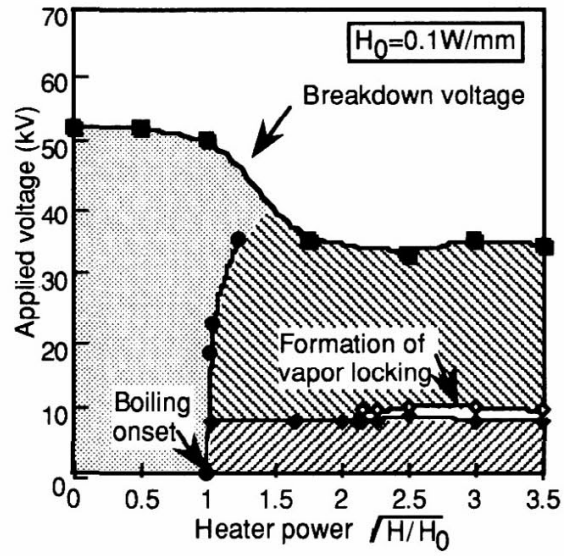

(b) Cylinder covered with non-pored film

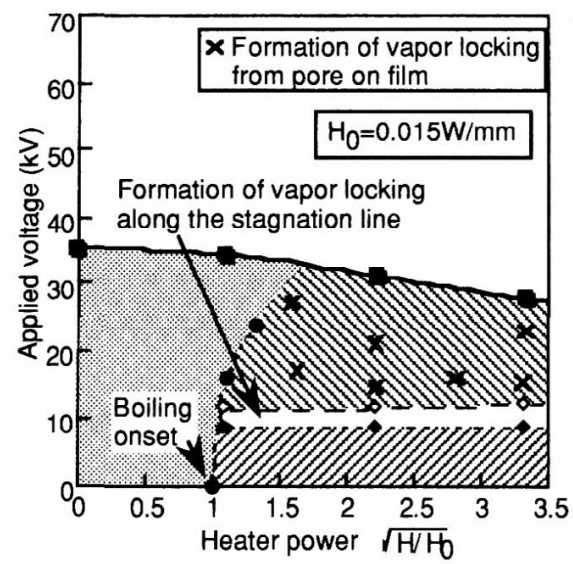

(c) Cylinder covered with pored film

図6 気泡挙動特性 $(\mathrm{g}=2 \mathrm{~mm}$ 、負極性)

Fig.6. Region of characterized bubble behavior for $\mathrm{g}=2 \mathrm{~mm}$.
る。

(5) 破壊電圧近くの高い電圧が印加されている時、ある 気泡発生の活性核から連続して気泡が発生する場合には、 気泡が連なる様子が見られる。特に最短ギャップ付近で は、円筒電極表面から真っ直ぐ平板電極の方に向かって気 泡が運動するため、ギャップ間を気泡が断続的に橋絡する 様子が観測される。

以上の実験結果は、すでに報告した気泡挙動の理論的検 討結果とよく一致する(7)(9)(11)。

以上のような観測を多数回行い、得られた $\mathrm{g}=2 \mathrm{~mm}$ の場 合の気泡挙動の観測結果をまとめたものが図6(a)である。 図中の"Gradient force dominant region"とは、電極の下部 より発生した気泡が、グレデイエントカに従い下方へと運 動する様子が観測されたことを示す。また、"Formation of vapor locking"とは、滞留位置で気泡の橋絡が観測された ことを示す。その電圧は破壊電圧よりもかなり低く、この 気泡の橋絡が直接破壊の経路とならないことが分かる。

フィルム有りの場合の気泡挙動を図7に、その特性をま とめたものを図6(b)に示す。円筒電極上にカプトンフィル ムを貼り付けても、絶縁破壊による放電痕がフィルム上に

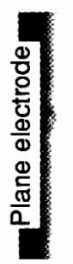

(a) $\mathrm{V}=0 \mathrm{kV}$

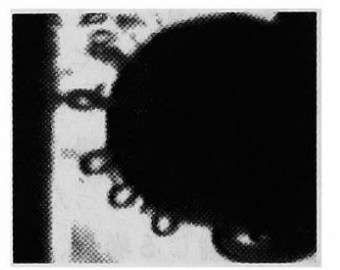

(b) $\mathrm{V}=6 \mathrm{kV}$
$\sqrt{\mathrm{H} / \mathrm{H}_{0}}=1.05, \mathrm{H}_{0}=0.4 \mathrm{~W} / \mathrm{mm}$, without pore on the film

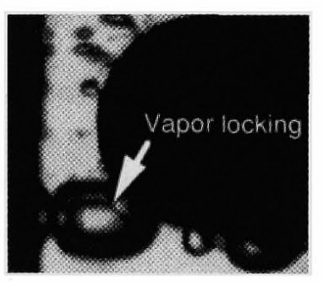

(c) $\mathrm{V}=10 \mathrm{kV}$

$\sqrt{\mathrm{H} / \mathrm{H}_{0}}=1.05, \mathrm{H}_{0}=0.4 \mathrm{~W} / \mathrm{mm}$, without pore on the film

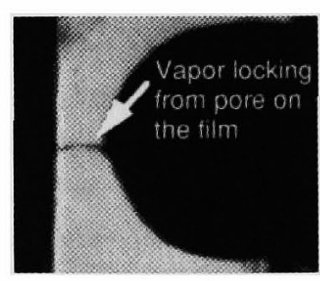

(d) $\mathrm{V}=27 \mathrm{kV}$

$\sqrt{\mathrm{H} / \mathrm{H}_{0}}=1.5, \mathrm{H}_{0}=0.015 \mathrm{~W} / \mathrm{mm}$, with a pore on the film
図7 フィルム有りの電極間の気泡挙動 $(\mathrm{g}=2 \mathrm{~mm}$ 、負極性) Fig.7. Bubbles with insulation film at $\mathrm{g}=2 \mathrm{~mm}$.

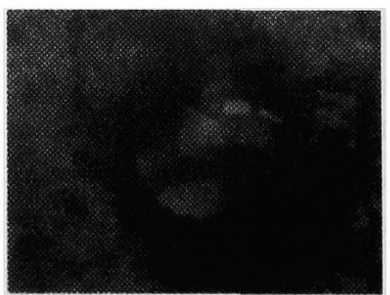

(a) Picture of pore

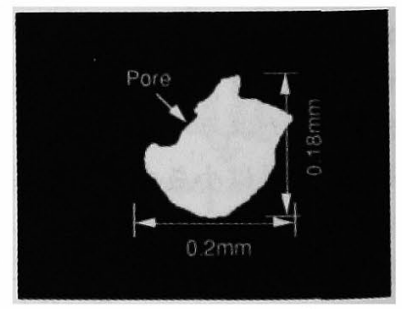

(b) Sketch of Fig.(a)
図8 フィルム上の放電痕

Fig.8. Pore formed on the film. 
形成される前は、孤立気泡挙動に対するフィルムの影響は 比較的小さかった。また、沸騰の開始されるヒータパワー $\mathrm{H}_{0}$ についても影響は少なかった。しかし、気泡発生の活 性核はフィルムの両端に集中するようになった。さらに、 フィルムなしの電極の場合と違い、図7(a)、(b)に示すよう に、電圧を印加することで気泡半径が大きくなった。この ため、気泡滞留位置での橋絡は、フィルムなしの場合より 小さいヒータパワーで発生した。

一方、フィルムを貼り付けた場合には、ギャップ長が長 ければ、絶縁破壊により容易にフィルム上に図8に示すよ うな放電痕を生じる。もしフィルム上に放電痕が生じれ ば、その場所は気泡の発生核になり易い。放電痕で発生し た気泡は、印加電圧がある程度高い値になると、気泡の根 元の移動が放電痕の境界部分に阻止されるので、平板電極 の方向へと伸び易くなる。その結果、図7(d)に示すよう に、 $\mathrm{g}=2 \mathrm{~mm}$ の長いギャップにおいても最短ギャップ領域 での気泡の橋絡が容易に発生した。図6(c)には、橋絡の発

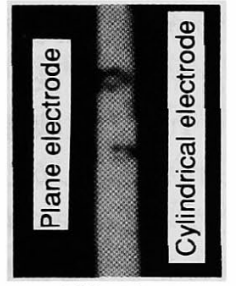

(a) $\sqrt{\mathrm{H} / \mathrm{H}_{0}}=1.05$, $\mathrm{H}_{0}=0.5 \mathrm{~W} / \mathrm{mm}$, without film

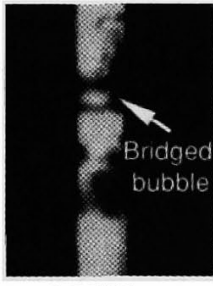

(b) $\sqrt{\mathrm{H} / \mathrm{H}_{0}}=1.5$, $\mathrm{H}_{0}=0.26 \mathrm{~W} / \mathrm{mm}$, with pored film
図9 円筒電極を垂直にした 場合の気泡挙動 $(g=1 \mathrm{~mm})$

Fig.9. Bubbles with vertically cyindrical electrode at $\mathrm{g}=1 \mathrm{~mm}$.

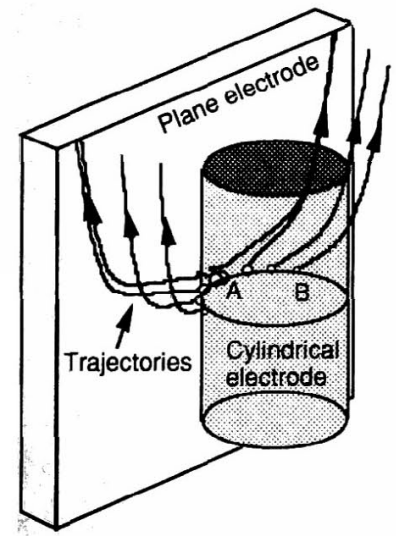

(a) Spatial view

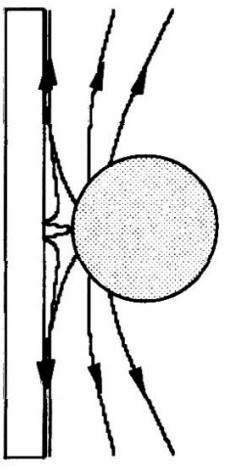

(b) Top view
図10円筒電極を垂直にした場合の

気泡軌跡のシミュレーション $\left(24 \mathrm{kV}, \mathrm{g}=2 \mathrm{~mm}, \mathrm{r}_{\mathrm{B}}=0.08 \mathrm{~mm}\right)$

Fig.10. Simulation of bubble motion with vertical electrode at $V=24 \mathrm{kV}$.
生開始が観測された電圧を×印で示した。この電圧は破壊 電圧よりもかなり低く、電圧を上昇させても破壊電圧に至 るまで、一旦形成された気泡橋絡は保持された。

円筒電極を垂直に配置にした場合の気泡挙動の様子を図 9に示す。また、垂直にした場合の気泡の軌跡を以前と同 じ仮定(11)のもとで数值計算により求めた結果を図10に示 す。これらの結果より、次のことが言える。グレディエン ト力と浮力の釣り合うような気泡の滞留位置は存在しな い。円筒電極表面から発生した気泡は、浮力の影響を受け つつ、グレディエントカにより最短ギャップから離れるよ うな水平方向の力を受ける。このため、気泡は上向きに運 動しつつ最短ギャップ領域を離れていく。

フィルムを電極上に貼った場合に放電痕が形成されてい ない状況で、特にフィルムの下の端から発生した気泡は、 水平配置の場合よりも大きくなっていた。これは浮力によ る気泡の上方への運動が絶縁フィルムの端で妨げられるた めと考えられる。また、これらの気泡は電圧印加によりさ らに大きくなる様に見えた。その大きさは図10に示すよう に最短ギャップ付近のAの方がギャップの外側のBよりや や大きい。つまり、電界が強い程絶縁フイルムの端にひっ かかった気泡が大きくなっており、これは平等電界中で絶 縁物に運動が阻止された電界下の気泡の挙動観測結果(3)と 同し現象と考えられる。

また、フィルム上に絶縁破壊による放電痕が発生する と、水平配置の場合と同様に、気泡は放電痕の所にひっか かり、そこから成長して平板電極に向かい筋状に伸びる現

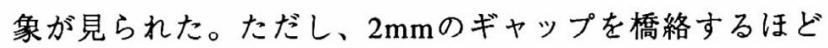
には長くなることは少なく、安定な気泡橋絡は図9(b)に示 すような $1 \mathrm{~mm}$ 程度以下のギャップ間においてであった。

\section{<3.2> 破棲電圧 図11にフィルムなし電極系で測定}

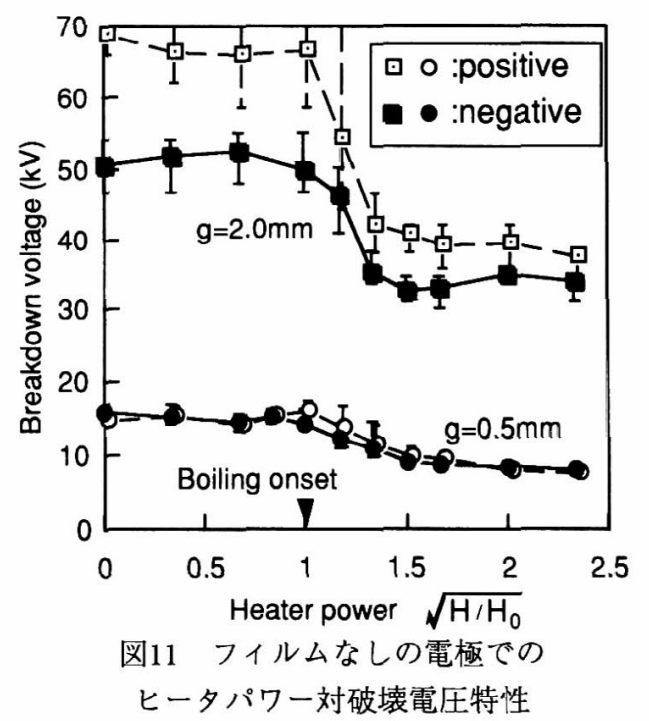

Fig.11. Heater power vs. breakdown voltage without insulation film. 


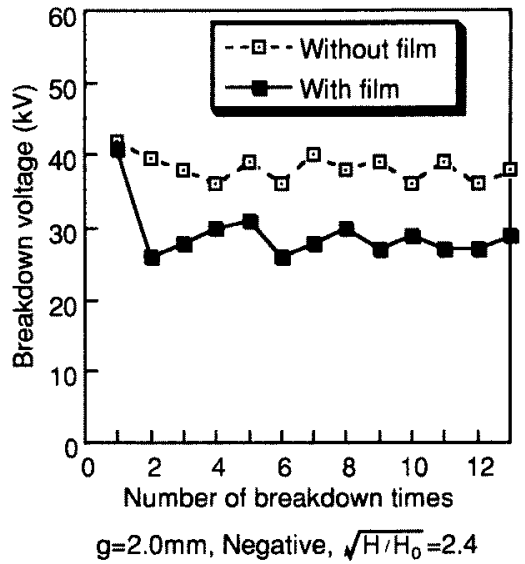

図12 破壊電圧の回数依存性

Fig.12. Dependence of breakdown voltage on breakdown times.

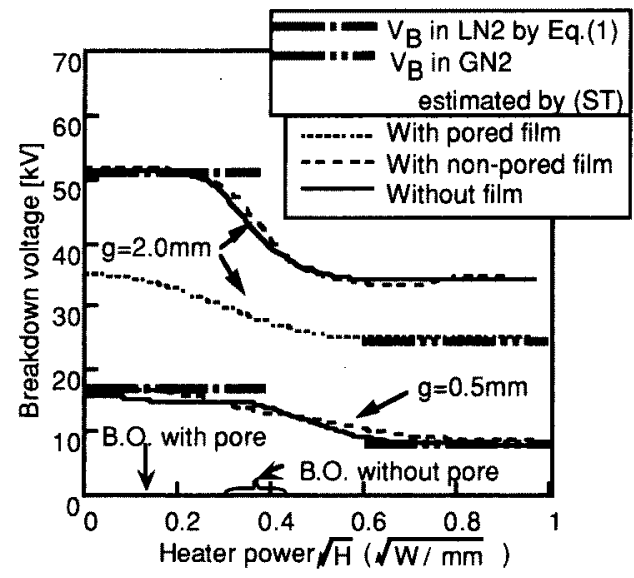

(a) Horizontally cylindrical electrode

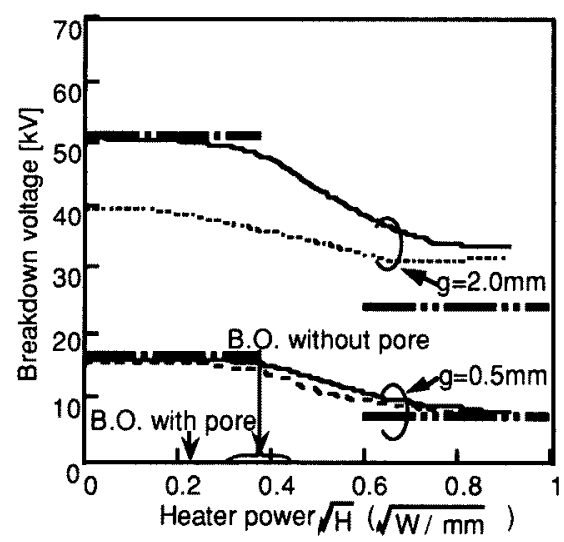

(b) Vertically cylindrical electrode

図13ヒータパワー対破壊電压特性

Fig.13. Heater power vs. breakdown voltage.

したヒータパワー対破壊電圧特性を示す。それぞれのHで 5 回ずつ破壊電圧を測定し、そのバラッキを絴棒で示し た。Hを上げていくと、気泡の発生が開始される $\mathrm{H}_{0}$ で、破 壊電圧の低下が始まり、ある電压に落ち着く様子が見られ る。また、破壊電压の低下時にバラツキが大きく発生して
いる。

極性効果はギャップ長が長い方が大きく、また、いずれ のギャップ長でも、負極性の破壊電圧の方が正極性の破壊 電圧よりも低い。このため、以降の破壊電圧は負極性の值 を示す。

また、ギャップ長が長い場合には、図12の例のよう に、フィルム有り電極系で破壊が発生すると以降の破壊電 圧が大きく低下する。これは図8に示したような放電痕て 成長する橋絡気泡の影響と考えられる。このため、絶縁破 壊後に、破壊電圧が大きく低下した場合には、デュワー中 の放電痕は外部から確認でさないが、以降の特性では放電 痕有りの場合として示す。

以上の上うな破壊電圧の測定を多数回行いまとめた円筒 電極を我平に配置した場合のヒータパワー対破壊電圧特性 の結果を図13(a)に示す。 $\mathrm{H}_{0}$ に対する絶縁フィルムの影響 を明らかにするため、ここではHの平方根の値を横軸に用 いた。破壊電圧に対するフィルムの影響は、ギャップ長や フィルム上の放電痕の存在に依存する。ギャップ長が $0.5 \mathrm{~mm}$ と短い場合には、絶緣破壊は常に円筒電極上のフィ ルムのない部分で発生する。このため、破壊電圧はフイル ムの影響をほとんど受けない。ギャップ長が長くなって も、フィルム上に放電痕がなければ、破壊電圧に対する フィルムの影響はほとんど見られない。しかし、ギャッフ 長が長くなって破壊電圧が高くなると、先にも述べたよう にフィルムを貫通して絶縁破壊の発生する確率が上昇し、 フィルム上に放電痕が生じると破壊電圧が急激に低下す る。また、 $\mathrm{H}_{0}$ も急激に低下し、この事により小さなヒー タパワーで破壊電圧の低下が始まるようになった。

従来の研究によると、液体窒素中の平等および準平等電 界下の破壊電圧測定値の下限は次式で近似される(4)。

$$
V_{B}=29 g^{0.8} \quad(\mathrm{kV})
$$

フィルムなしか、フィルムに挰傷のない状況で、ヒータパ ワーのない場合の破壊電圧は、ギャップ長に関わらず、 (1)式で得られる值と同程度である。一方、フィルムに損 傷のある状況で、ヒータパワーの大きい場合はストリーマ 理論(ST)から推定される空素ガスの破壊電圧值(12)にかな り近づく。

円筒電極を垂直に配置した場合の破罗電圧特性を図13 (b)に示す。この時、水平配置の場合とは異なり、 $\mathrm{g}=2 \mathrm{~mm}$ の場合には、放電痕が生じてヒータパワーが大きい場合に おいても、破壊電圧が窒素ガスの值まで低下することはな かった。これは、先にも述べたように、放電痕から発生し 成長した気泡が $2 \mathrm{~mm}$ のギャップ長を橋絡するすることが

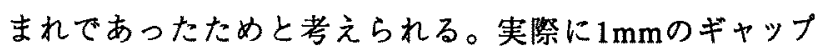
を橋絡する程度の気泡は容易に観測され、その場合には、 窒素ガスの值まで破壊電圧が低下した。

\section{4. 考察}

\section{<4.1> 気泡挙動に与える絶緑フィルムの影縤}


電極表面からの気泡の発生、成長および運動に与える絶 緑フィルムの影響因子は、3つに大別できる。第一は、 フィルムによる電極と液体間の熱伝達阻止によりフィルム 端での温度上昇が起こり $\mathrm{H}_{0}$ が低下すると同時に、そこで の気泡サイズがフィルム無しの場合より大きくなることで ある。この気泡サイズのフィルムによる増大は、気泡運動 に対する見掛け上の粘性効果の低減に繋がり(11)、気泡挙 動の活発化をもたらす。第二は、フィルム端の金属と絶縁 物境界付近では気泡の電極沿面に沿った運動が妨げられや すく、特に円筒電極を垂直に配置した場合には上方への気 泡の滑りを妨げる効果が顕著になることである。これら は、Hが同じ場合、気泡サイズを大きくするように作用 し、第一の影響と結果的には同じになる。第三は、フィル ム上に放電痕が形成されることによる沸腾の活性核の形成 と放電痕の周りの境界における電極面に沿った気泡の滑り 阻止効果である。これは、結果的には放電痕における気泡 の安定な成長をもたらし、図7(d)の様な気泡橋絡に慗が る。

フィルムによる顕著な破壊電圧低下の原因という観点か らすれば、この気泡橋絡の原因となるフィルム上での破壊 による放電痕の形成条件を見いだすことが大切である。そ こで、新たにフィルムの破壇電圧を先端半球状の棒対平板 電極系にフィルムを挟んで調べた。その結果が図14であ る。これによると、負棒の場合電極先端の曲率にもよる が、破壊電压は18２7kVの範囲にある。ここで検討して いる円筒対平板電極系のフィルム有り/無しにおける ギャップ長を変えた破壇電圧特性と放電痕の観察および図 14より、液体の破壊電圧がフィルムの耐電压を上回るよう なギャップ長になると、フィルム上に放電痕が形成される 確率が高くなることが認められた。

次に、円筒電極配置を変えた場合にフィルムの気泡挙動 に与える影響がどのように変わるかについて述べる。配置 を垂直に変えると、浮力とグレディエントカが釣り合う位 珇がなくなり、孤立気泡ならびに電極に接触した気泡は常 に上向きの力を受ける。これは、気泡の安定成長を阻止す るように作用し、フイルム端や放電痕からの気泡橋絡が安 定に維持されるギャップ長の隇少に慗がり、<3.1>の観測 結果とも一致する。

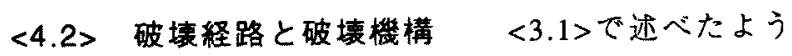
に、裸電極で気泡橋絡が発生するにも関わらす、破䧇が橋 絡のない最短ギャップで起きるのは、先の報告の中で検討 した(11)ように、電壬が高くなるとダレディエントカが大 きくなって橋絡形成位置が最短ギャッフから遠ざかり、そ こでのガス中の破壊電圧より最短ギャップの液中における 破壊電压の方が低いためである。

さらに、裸電極の時は变形気泡と夜体の混在した複合絶 縁系の破壊になり、ヒータパワーが大きくなるに従って気 泡の割合が大きくなって破壊電圧が低下する。フィルム有 りで放電痕が形成された場合には、放電痕から成長する気
泡がギャップを橋絡し、ヒータパワーが大きくなるとこの 橋絡気泡の径が大きくなるとともに気泡内のガス密度が低 くなって破壊電圧が低下するために、破壊電压はヒータパ ワーとともにガス中の值まで低下したものと考えられる。

ところで、Krasuckiの理論(13)を用いて平等電界中の孤 立球形気泡を仮定して図5の電界条件下で気泡の変形率を 推定すると、長軸と短軸の比が $1.1 \sim 1.3$ 程度となる。これ は図5に示した筋状の気泡の変形率よりも明らかに小さ い。これは、特に図5(b)のような筋状の気泡形成は、 Krasucki理論の「平等電界の球状気泡」の仮定がくずれ、 気泡成長時におけるマッシュルーム状の長い気泡(14)にマ クスウェル応力が作用した結果、気泡の変形が促進された ことによると考えられる。

さらに、破壊機構と熱気泡存在下での破壊電圧の大きな バラツキの原因を解明するために、破罗電圧の確率密度分 布の計測を行った。その結果を図15に示す。この場合、 それぞれのヒータパワーで50回程度の破壊を測定してい る。いずれのギャップ長や極性においても、ヒータパワー の増加による破壇笔圧の低下が著しい領域で2つの分布の 重なりとなった。これは、気泡挙動と密接に関係してい る。すなわち、沸滕開始付近では、電界印加による冷却促 進により電圧上昇途中に沸騰が止んだり、気泡が最短 ギャップから突然に吹き払われたりする現象が出現した。 図6で、自然対流を起こすヒータパワーが印加電圧ととも に大きくなっているのはこの電界による冷却促進効果の表 れである。観測によると、最短ギャッブ領域から気泡が突 然吹き払われる現象は確率的なもので、電圧印加前に予測 できるものではない。その根本原团は電界にあるが、これ が夜体の運動にどのように作用して吹き払い効果が現れる のかについては今後の研究を待たなければならない。この 吹き払い効果が現れて最短ギャップ領域に気泡がなくなる 場合には、図15の二つの瘤を持つ分布の高い破壊電圧側の データとなり、破壊まで気泡が存在すると低い破壊電圧側 のデータとなる。ヒータパワーが大きくなるに従い、吹き

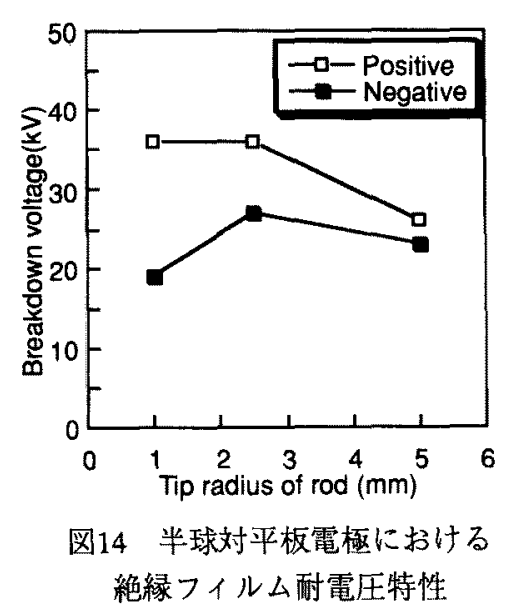

Fig.14. Breakdown voltage of tested film measured with a semi-spherical capped rod-to-plane gap. 
払い効果の出現確率は低くなり、破壊電圧はガス中の值に 近今く。

<4.3> 破壤特性に与える絶縁フィルムの影譬

絶椂フイルムが破壤電压に与える影響因子は、2つに大

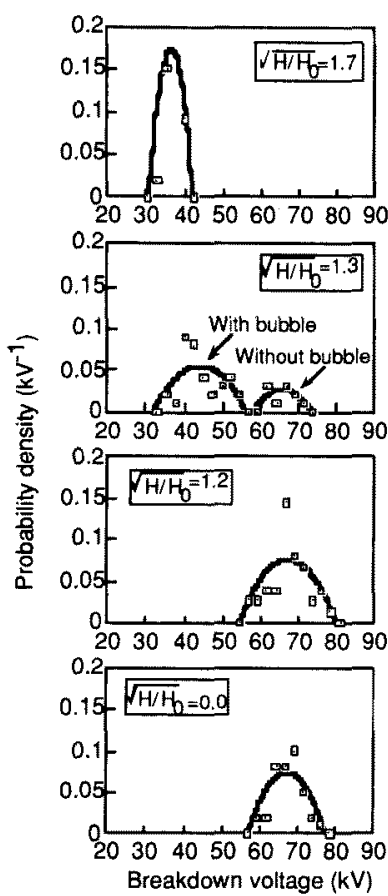

(i) positive
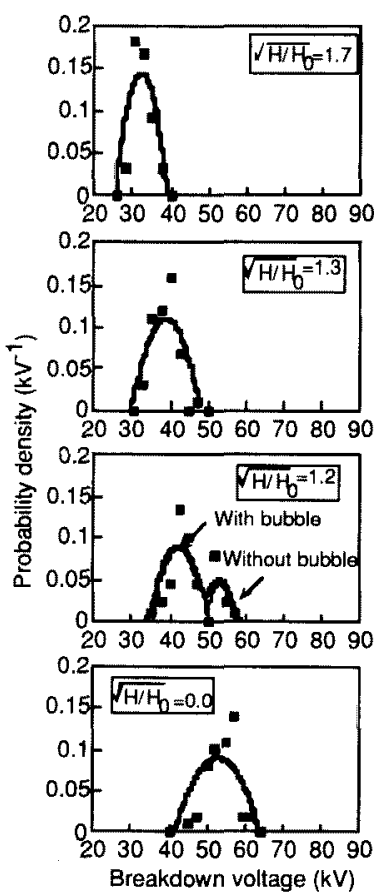

(ii) negative (a) $\mathrm{g}=2 \mathrm{~mm}$

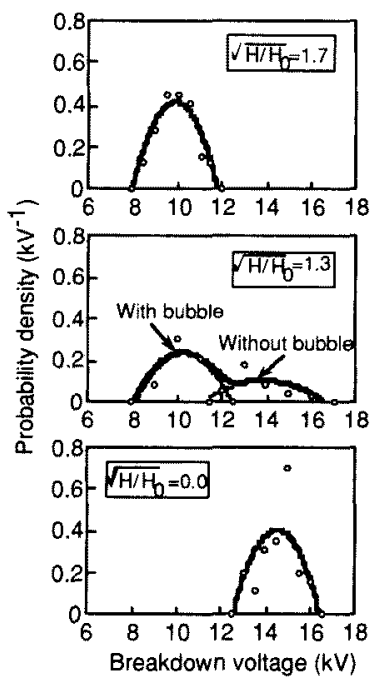

(i) positive

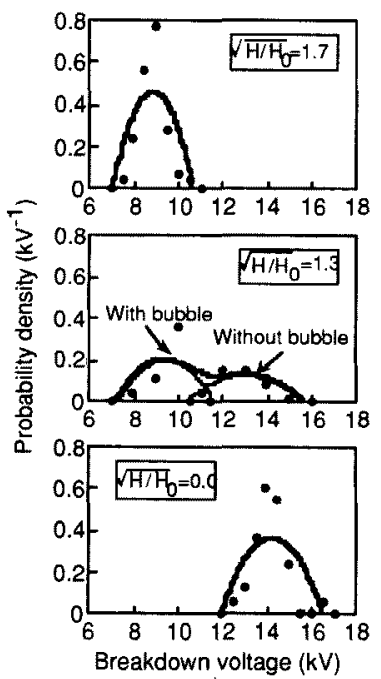

(ii) negative (b) $g=0.5 \mathrm{~mm}$

図15フィルムなし電極における 破壊電压の確率密度分布

Fig.15. Breakdown voltage density distributions at diffrent heater power for negative polarity with bared cylinder.
別できると考えられる。一つは、フィルムの存在による電 界歪み、もう一つは気泡挙動への影響を通しての因子であ る。これらを破壊特性上で完全に分噰して見ることは難し い。たとえば、ヒータパワーを一定にしてフィルム有り 無しの破壊電圧を比較すると、電界歪みの効果が陽に出現 しそうに思われる。しかし、本実験系ではフィルムの有 り/無しで液体の蒸発量は変わらないが、気泡の大きさと ギャップ中における分布が変わり、電界歪み以外の効果も 破壊電圧に現れる。しかし、電界歪みの効果はH一定下て フィルム有り/無しの破罣電压の比較より、また、熱気泡 の挙動の変化による効果は与えられた電極でヒータパワー を変えたときの破壊電圧の比較により、ある程度推定でき ると考えられる。この観点から図13を調べると、放電痕が ある場合の電界歪み効果が気泡効果に比べて同程度かそれ 以上であると言える。特に、 $\mathrm{g}=2 \mathrm{~mm} 、 \mathrm{H}=0$ においてフィ ルム有り/無しで大きな差が出ているが、これは放電痕に おける電界歪み効果の寄与が大きいためと考えられる。し かしこの場合も、前の放電による放電痕にトラップされた 気泡の寄与もゼロではないであろう。

何れにしても、超伝導コイルのクエンチ環境下で固体絶 縁物が一度破壊を経験すると、破壊前の系の耐電圧が高い ほど絶縁劣化の程度が大きくなる。

\section{5. むすび}

本諭文では、液体窒素中での熱気泡を介した絶縁破壊に 対する絶縁フィルムの影響について、検討を行った。その 結果を要約すると次のようになる。

(1) 気泡挙動に対するフィルムの影響は、フィルムによ る気泡発生に対する影響とフィルム端及び放電によって形 成された小孔における気泡のひっかかりによる成長促進を 通して主に出現する。

(2)フィルムが存在する場合でも、孤立気泡に作用する グレディエント力によって気泡集塊または橋絡が発生する が、破壊電圧低下の原因は最短ギャップ付近に存在する変 形気泡か、放電痕から成長する橋絡気泡で、グレディエン ト力の作用によって成長した大きな気泡が破壊電圧低下の 原因になることは少ない。

(3) 破壞電圧は、フィルム上に放電痕が形成されること によって著しく低下し、その最低值は77Kの窒素ガス中の 值に近い。

(4) フィルム上の放電痕の形成は、夜体の破壊電圧が フィルムの耐電圧より大きくなるギャップにおいて高い確 率で出現する。

(5) 超伝導コイルのクエンチ環境下で固体絶縁物が一度 破壊を経験すると、破壊前の系の耐電圧が高いほど絶縁少 化の程度が大きくなる。

本研究の一部は、文部省科学研究補助金基盤研究によっ た。

(平成 9 年 2 月 10 日受付、平成 9 年 5 月 26 日再受付) 


\section{文献}

(1) 新エネルギー・産業技術総合開発機構：超電導電力応用技 術開発トータルシステム等の研究導入効果の調査研究、平 成7年度 委託業務成果報告書 (1996)

(2) K.Funaki, M.Iwakuma, M.Takeo, K.Yamafuji, J.Suehiro, M.Hara, M.Konno, Y.Kasagawa, K.Okubo, Y.Yasukawa, S.Nose, M.Ueyama and K.Hayashi: "Design and Construction of a 500kVA-Class Oxide Super Conducting Power Transformer Cooled by Liquid Nitrogen", Proc. of 16th ICEC, Kitakyushu, Japan (to be published)

(3) M.Hara, T.Kaneko and K.Honda: "Electrical Breakdown mechanism of liquid nitrogen in the presence of thermally induced bubbles", Cryogenics, Vol.27, pp.93-101 (1987)

(4) M.Hara, T.Kaneko and K.Honda: "Thermal-Bubble Initiated Breakdown Characteristics of Liquid Helium and Nitrogen at Atmospheric Pressure", IEEE Trans. on Electrical Insulation, Vol.23, No.4, pp.769-778 (1988)

(5) M.Hara and M,Kubuki: "Effect of thermally induced bubbles on the electrical breakdown characterictics of liquid nitrogen", IEE Proceedings, Vol.137, Pt,A, No.4, pp.209216 (1990)

(6) M.Hara, Z-C.Wang and H.Saito: "Thermal-Bubble Behavior Affecting Dielectric Characteristics in Liquid Nitrogen under Non-uniform Fields", Proc. of 8th ISH, Yokohama, Japan, No.93.01 (1993)

（7）原雅則、才田健二、䶓藤弘勝:「不平等電界下における極低 温液体中の熱気泡挙動の解析」電気学会論文誌 $\mathrm{A}, \mathrm{V}$ ol.113A, No.4, pp.337-344 (1993)

（8）原雅則、王振朝、齋藤弘勝、村松悟:「夜体窒素中における 不平等電界下の熱気泡挙動」電気学会論文誌A, Vol.113-A, No.12, pp.817-826(1993)

（9）王振朝、吉塚博康、原雅則:「極低温液体中に扔ける直流電 界下の気泡運動の解析」電気学会論文誌A,Vol.115-A, No.3, pp.265-272(1995)

(10) N,Hayakawa, M,Hirose, H, Goshima, M,Hikita, K, Uchida and H,Okubo: "Quench-induced breakdown characterics of liquid helium and optical observation of thermal bubbles", Cryogenics, Vol.35, No.2, pp,135-142

(11) 松浦俊輔、高野浩二、江岩、末廣純也、原雅則:「液体窒素 中の気泡挙動に対する電界分布の影響-理論による検討-」 電気学会放電研究会資料 No.ED-96-231(1996)

(12) M.Hara, J.Suehiro and H.Matsumoto: "Breakdown Characteristics of Cryogenic Gaseous Nitrogen and Estimation of its Electrical Insulation Properties", IEEE Trans. on Electrical Insulation, Vol.24, No.4, pp.609-617 (1989)

(13) C.G.Garton, and Z.Krasucki:"Bubbles in Insulating Liquids: Stability in Electric Field", Proc. Roy.Soc, A280, pp.211226(1964)

(14) R.F.Gaertner:"Photographic Study of Nucleate Pool Boiling on a Horizontal Surface", Journal of Heat Transfer, February, pp.17-29 (1965)

（学生員）1969年1月13日生。91年3月九 州大学電気工学科卒業。93年3月九州大学 大学院工学研究科修士課程修了。同年4月 九州電力株式会社入社。96年4月九州大学 システム情報科学研究科博士課程入学。 超伝導機器の電気絶縁に関する研究に従 事。

松浦 俊輔 (学生員) 1974年3月31日生。96年3月九

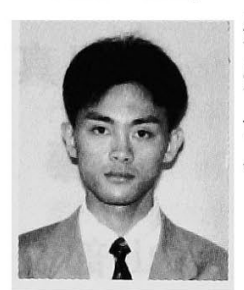
州大学工学部電気工学科卒業。同年4月九 州大学大学院システム情報科学研究科修 士課程入学。超伝導機器の電気絶縁に関 する研究に従事。

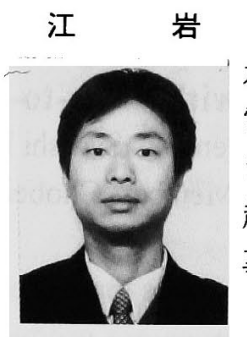

（学生員）1967年2月2日生。88年7月武漢 水利電力大学電気工学科卒業。中国福建 電力会社を経て、95年4月九州大学大学院 システム情報科学研究科修士課程入学。 超伝導機器の電気絶縁に関する研究に従 事。

末展 純也

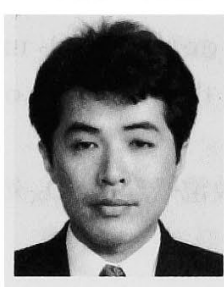

（正員）1961年3月9日生。83年3月九州大 学工学部電気工学科卒業。85年3月九州大 学大学院工学研究科修士課程修了。同年4 月新日本製鐵入社、 88 年 4 月九州大学工学 部助手、92年4月同助教授、現在に至る。 主として、極低温放電現象、および静電 細胞操作に関する研究に従事。博士（工 学）。95年電気学会論文賞受賞。静電気学会、低温工学 会、日本生物物理学会員。

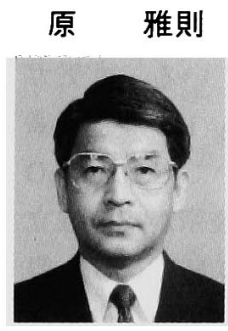

（正員）1942年4月13日生。72年3月九州 大学大学院工学研究科博士課程修了。九 州工業大学講師、助教授、九州大学助教 授を経て同教授。現在、九州大学大学院 システム情報科学研究科(http://www.isee. kyushu-u.ac.jp)所属。電力工学、高電圧 パルスパワー工学、超電導工学、バイオ 工学に関する研究に従事。工学博士。IEEE Senior、低温 工学協会, 静電気学会、放電研究グループ会員。 